 \\ Invertebrate Reproduction \& Development
}

\section{Geographical variation and local environment effects in the reproductive output and fecundity of the shrimp Exhippolysmata oplophoroides (Decapoda: Caridea) in southeastern Brazil}

Gilson Stanski, Mariana M. Carvalho, Joyce R. Garcia, Geslaine R. L. Goncalves, Rogério C. Costa \& Antonio L. Castilho

To cite this article: Gilson Stanski, Mariana M. Carvalho, Joyce R. Garcia, Geslaine R. L. Goncalves, Rogério C. Costa \& Antonio L. Castilho (2018) Geographical variation and local environment effects in the reproductive output and fecundity of the shrimp Exhippolysmata oplophoroides (Decapoda: Caridea) in southeastern Brazil, Invertebrate Reproduction \& Development, 62:2, 119-124, DOI: 10.1080/07924259.2018.1448305

To link to this article: https://doi.org/10.1080/07924259.2018.1448305

曲 Published online: 10 Mar 2018.

Submit your article to this journal $[\pi$

山 Article views: 113

View Crossmark data ¿

Citing articles: 1 View citing articles $\longleftarrow$ 


\title{
Geographical variation and local environment effects in the reproductive output and fecundity of the shrimp Exhippolysmata oplophoroides (Decapoda: Caridea) in southeastern Brazil
}

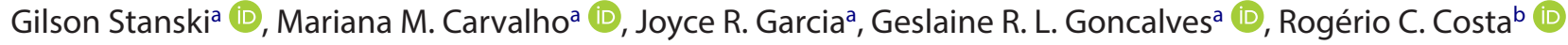 \\ and Antonio L. Castilho ${ }^{a}$
}

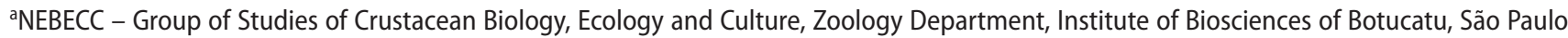
State University, Botucatu, Brazil; 'baboratory of Biology of Marine and Freshwater Shrimp, Biological Sciences Department, Faculty of Sciences, São Paulo State University, Bauru, Brazil

\begin{abstract}
We studied the shrimp Exhippolysmata oplophoroides in southeastern Brazil (Macaé, 22037"S; Ubatuba, 23055"S; and Cananéia, 25053"S) to test the hypotheses that (1) females should have the same reproductive output and fecundity at the regional scale, and (2) these reproductive parameters can vary among regions. Maximum carapace length (Macaé $=13.1 \mathrm{~mm}$, Ubatuba $=12.8$, Cananéia $=16$ ), fecundity, and reproductive output differed among regions (Ancova, $p<0.05$ ). Females in Cananéia exhibited the highest reproductive output/fecundity (18.6\%/5230 embryos), followed by those in Macaé (16.0\%/4365 embryos) and Ubatuba (12.6\%/1206 embryos). We found that fecundity/reproductive output varies inversely with the length of the reproductive season, i.e. a considerable amount of energy is allocated during seasonal spawning periods in subtropical regions such as Cananéia. Previous studies have proved that $E$. oplophoroides is able to reproduce continuously in Ubatuba, with probably minor but continuous energy investment in reproduction occurring in this tropical region. In contrast, although Macaé is located at tropical latitude, it is under the influence of Cabo Frio upwelling that alters the water's physical properties via cold water intrusion. This process may be a determining factor in the spawning seasonality of Macaé's shrimp population, justifying the higher reproductive output recorded here than in Ubatuba.
\end{abstract}

\section{ARTICLE HISTORY}

Received 19 December 2017

Accepted 1 March 2018

\section{KEYWORDS}

Bycatch; latitudinal pattern; marine front; Pleocyemata

\section{Introduction}

Coastal fisheries in southeastern Brazil are currently overexploited due to non-selective trawling (Pezzuto and Benincà 2015). Such methods aim to capture penaeid shrimps such as Farfantepenaeus paulensis (Pérez-Farfante 1967), F. brasiliensis (Latreille 1817), Litopenaeus schmitti (Burkenroad 1936), and Xiphopenaeus kroyeri (Heller 1862), which are sold commercially and thus support the subsistence of hundreds of fishermen and those working in regional tourism (Valentini et al. 1991; Garcia et al. 2016). Because it is non-selective, such fishing methods also affect other non-commercial animals taken in the trawls, known as the bycatch, including the caridean shrimp Exhippolysmata oplophoroides (Holthuis 1948), which shares the same habitat as penaeid shrimps, especially during the reproductive period when females incubate embryos in their abdomen.

Exhippolysmata oplophoroides plays a fundamental ecological role in the region as a member of the trophic chain, being the most abundant caridean species on the coast of São Paulo state and serving as food for various invertebrate and fish species (Chacur and NegreirosFransozo 1999; Costa et al. 2000). As a result, it is an important model used in studies examining the effect of fisheries on bycatch fauna in terms of fecundity and reproductive output.

Bauer (1992) and Castilho et al. (2007) previously demonstrated the 'latitudinal effect paradigm' in penaeid and caridean prawns, in which reproductive periodicity and fecundity tend to increase as latitude decreases. This paradigm has generated various hypotheses regarding specific environmental stimuli (proximal factors) and selective pressure (final factors) that act on the life habit of the species in question.

Prompting the evaluation as to whether reproductive fluctuations are responses to either environmental changes with latitudinal gradient, or anthropogenic activity. However, many exceptions can arise, especially due to regional environmental phenomena such as maritime fronts, which can change the expected environmental 
scenario. One example of such a phenomenon is the thermal front caused by the upwelling of cold water at the Cabo Frio (Rio de Janeiro), which alters the expected physical pattern of the water column in tropical regions.

The present study aimed to establish the presence of any variation in the reproductive characteristics of the shrimp E. oplophoroides on a regional tropical - subtropical scale ( $22^{\circ} \mathrm{S}-25^{\circ} \mathrm{S}$ latitude) along the south-eastern Brazilian coast. Thus, we proposed the hypothesis that fecundity/reproductive output varies with latitude in E. oplophoroides in south-eastern Brazilian waters. This hypothesis was tested by observations and measures on embryo production, body size distributed across three locations: two tropical regions of Macaé (Rio de Janeiro) and Ubatuba (São Paulo), and the subtropical region Cananéia (São Paulo).

\section{Material and methods}

Sampling was carried out along the south-eastern coast in the regions of Macaé (RJ), Ubatuba (SP), and Cananéia (SP), during the years 2012 and 2015. Collection was standardized across the three sampled regions, and involved the use of a shrimp boat equipped with double-rig nets. Sampling station sites were previously determined based on depth (5-20 m). All sampling areas were recorded
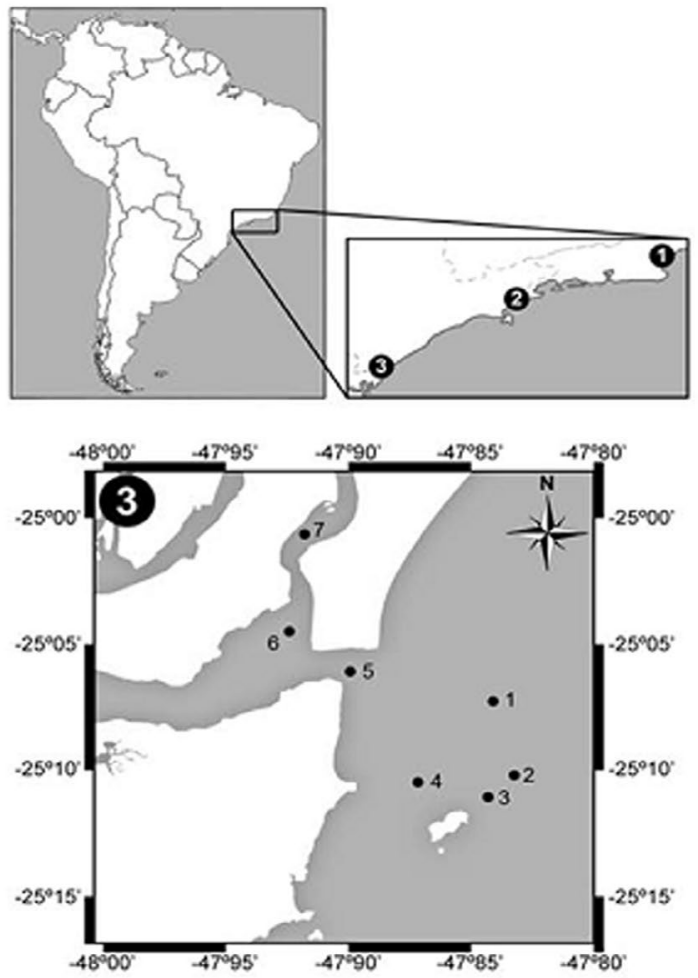

according to their geographical coordinates with a GPS (Global Positioning System) (Figure 1).

The netted shrimps were sorted, bagged, labeled, and placed in ice-filled thermal boxes on the boat, before being fixed and transported to the Study Group on Crustacean Biology, Ecology and Culture (NEBECC) at São Paulo State University, Botucatu (SP). In the lab, individuals of E. oplophoroides were identified (Williams 1984) and females with embryos in their pleopods measured in terms of length of carapace $(\mathrm{CL})$ using a $0.01 \mathrm{~mm}$ precision caliper.

Embryos were carefully removed from the pleopods with fine needles and, quantified using a manual counter and then classified according to their embryonic development as follows: stage I, high concentration of yolk and non-visible eyes; stage II, embryo eyes present and a lower concentration of yolk (Terossi et al. 2010). All subsequent analyses involved the measurement of only females with embryos in the initial stage of development (stage I), to avoid the analysis of those subject to egg losses (Terossi et al. 2010).

Fifteen embryos were randomly selected for the measurement of the smallest and largest egg axes, with these data then used to calculate egg volume as $\mathrm{VO}=$ ( $\pi(e 1) 2 . e 2) / 6$ (Turner and Lawrence 1979), where e1 represents the average of the larger axes and $e 2$ represents the average of the smaller axes.
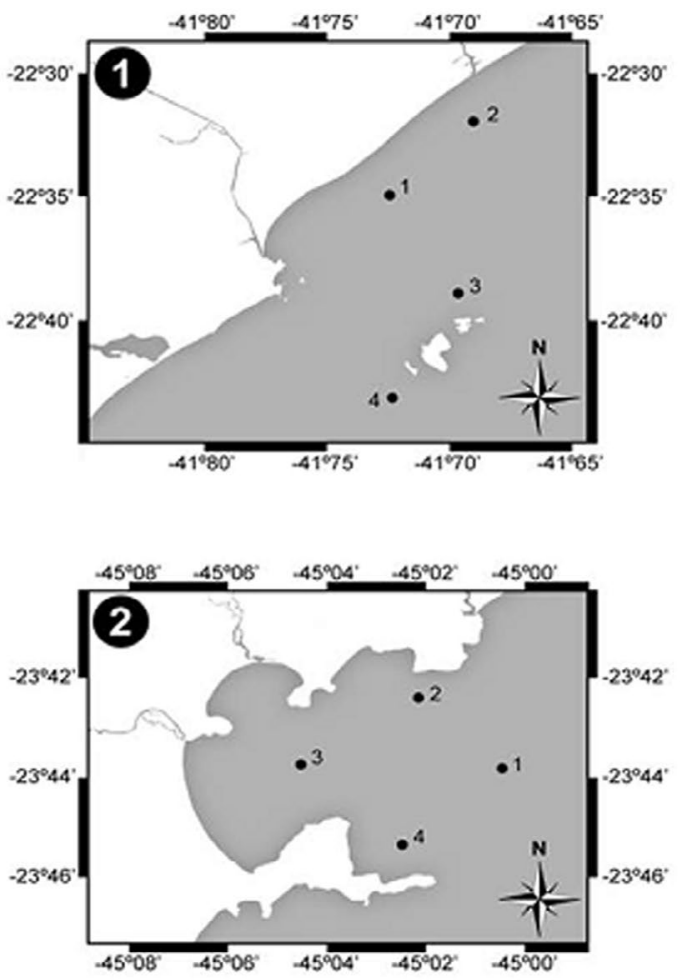

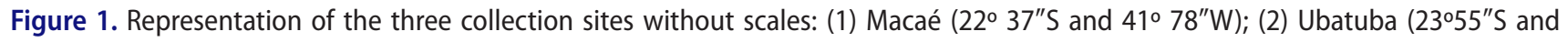
$\left.46^{\circ} 20^{\prime \prime W}\right)$; (3) Cananéia (25053"S and 47036"W) (Source: Author). 
After counting, the animals, as well as their respective masses of embryos, were placed in an oven $\left(60^{\circ} \mathrm{C}\right)$ for $48 \mathrm{~h}$ to obtain the dry weight of both the embryos and that of the females (without embryos), via the use of an analytical balance with a precision of $1 \mu \mathrm{g}$. Reproductive output (RO) was then calculated based on these two measurements as $\mathrm{RO}=$ total mass of embryos/ mass of female without embryos (Clarke 1987).

Simple linear regression analyses were performed to establish the relationship between: fecundity vs $\mathrm{CL}$; egg volume vs $\mathrm{CL}$; reproductive output vs $\mathrm{CL}$; and egg weight vs female weight. Covariance analysis (Ancova), using CL as covariance, was also applied to compare the number, embryo volume, and reproductive output of the three populations sampled. During all statistical analyses, the assumptions of parametric tests were met, with the variable data square-root transformed because they did not present a normal distribution (Zar 1999).

\section{Results}

Thirty-eight females with embryos in their pleopods were analyzed, ranging in size from $9 \mathrm{~mm} \mathrm{CL}$ to $13.1 \mathrm{~mm}$ in Macaé, $12.8 \mathrm{~mm}$ in Ubatuba, and $16 \mathrm{~mm}$ in Cananéia
(Ancova, $F=3.8, p<0.05)$. Cananéia females exhibited the highest reproductive output (18.6\%), followed by those in Macaé (16.0\%) and Ubatuba (12.6\%) (Ancova, $F=5.1$, $p=0.01)$. The same pattern was recorded for egg numbers, with the most observed in Cananéia (204-5230 embryos), followed by Macaé (130-4365 embryos) and Ubatuba (61-1206 embryos) (Ancova, $F=5.28, p=0.01$ ). There was no difference between the three populations in terms of volume of embryos (Ancova, $F=0.62, p=0.54$ ) (Figure 2).

A positive relationship was found between number of embryos and size of females in each of the three sampled regions (Macaé, $R^{2}=0.75$; Ubatuba, $R^{2}=0.60$; Cananéia, $R^{2}=0.50$ ) (Figure 3 ), as well as between egg weight and female weight (Macaé, $R^{2}=0.75$; Ubatuba, $R^{2}=0.75$; Cananéia, $R^{2}=0.50$ ) (Figure 3).

\section{Discussion}

Variation in female shrimp reproductive output, number of embryos and size reflects a reproductive adjustment to regional environmental conditions. In many crustaceans, reproductive processes depend on hormone control, photoperiod, rainfall (Little 1968), phases of the moon or tides (Warner 1977), and salinity changes (Batoy et al. 1987).
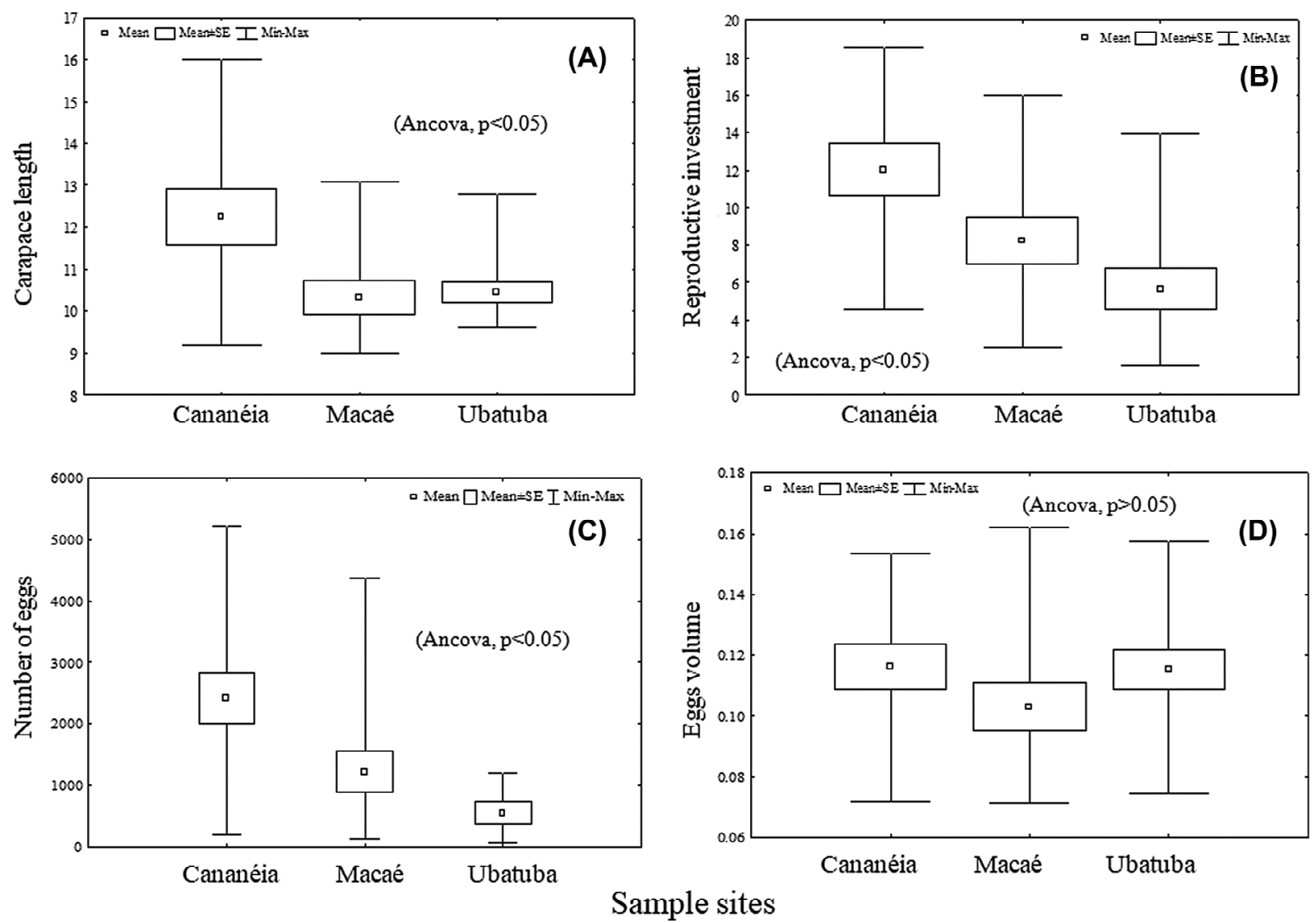

Figure 2. Variation in carapace length (A), reproductive output (B), number of embryos (C), and egg volume (D) of Exhippolysmata oplophoroides in the three studied regions (Cananéia; Ubatuba; Macaé). 

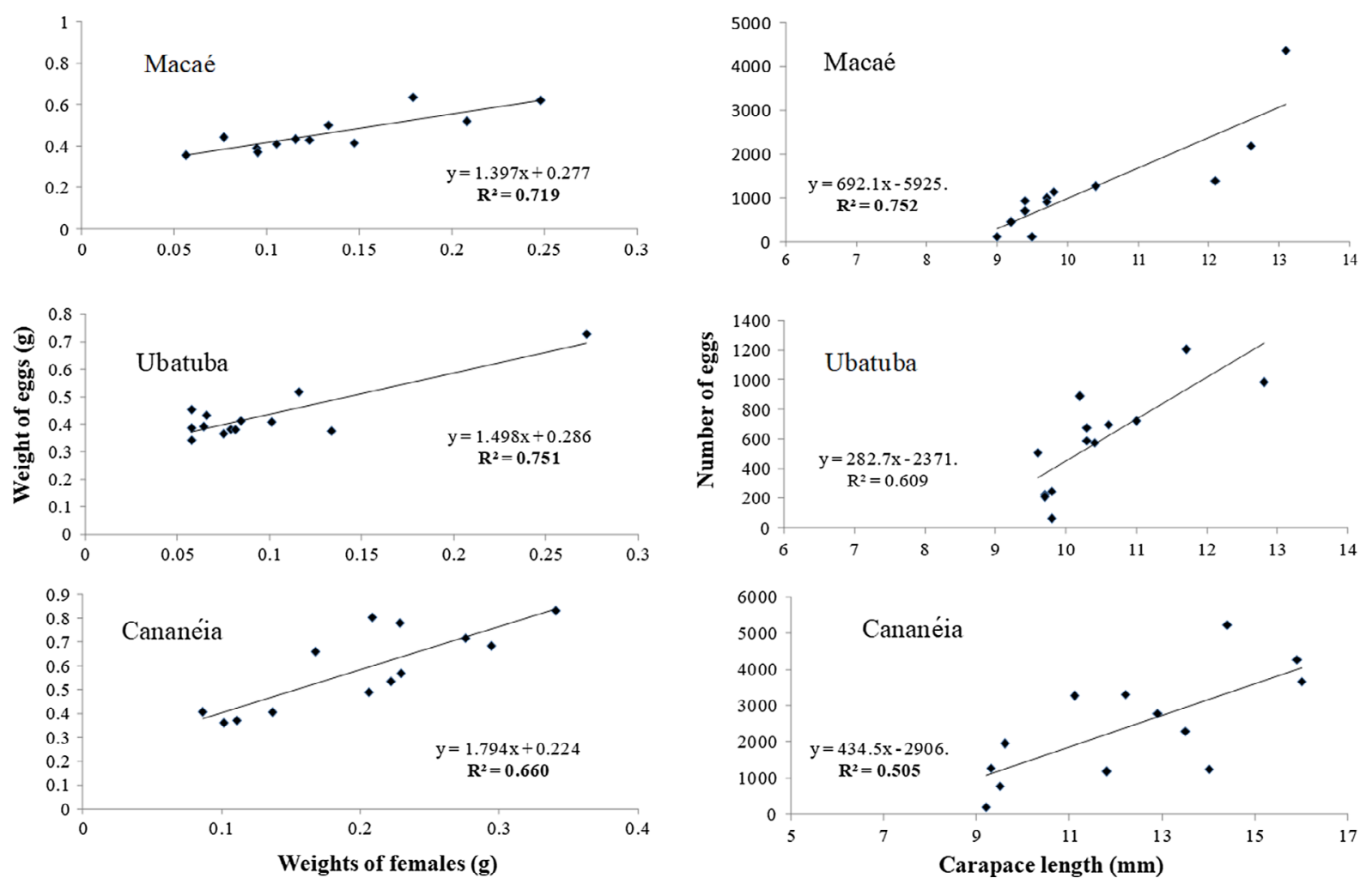

Figure 3. Regression analysis between the dry weight of embryos and dry weight of females, and between the number of embryos and the size of females (carapace length), for Exhippolysmata oplophoroides sampled in Macaé, Ubatuba, and Cananéia.

However, the main influencing factor is temperature, which not only affects the abundance of food for larvae (Goodbody 1965; Lancaster 1990), but is also of great importance for the maintenance of gametogenesis and ovarian development, which in turn define the reproductive period of the species (Bauer 1992).

Species with wide geographical distributions have the ability to adjust their metabolism when exposed to changes in the environment. An influx of cooler waters, for example, tends to direct reproductive periodicity to coincide with episodes of environmental conditions that are favorable to embryo development (Laufer and Landau 1991; Quackenbush 1994; Fingerman 1995). Thus, the high reproductive output and number of embryos found in $E$. oplophoroides in the Cananéia region can be considered a strategy of the species to maximize its reproductive success in an area with a shorter reproductive season. Cananéia $\left(25^{\circ} \mathrm{S}\right)$ is located in a subtropical region in which the seasons are well defined, with rigorous winters and warm summers (Kutner 1972; Garcia et al. 2016). As a consequence, the highest primary productivity will occur in the spring-summer period (Pires-Vanin and Matsuura 1993).

The greater availability of food (primary productivity) is one of the most influential factors in the reproductive seasonality of marine organisms, including the breeding and spawning periods of crustaceans (Thorson 1950; Dall et al. 1990; Bauer 1992). Species with planctotrophic larval stages, such as E. oplophoroides, allocate greater reproductive energy in periods of the highest oceanic productivity, since these periods are characterized by greater food availability (phytoplankton) for larval offspring. Stanski and Castilho (2016) recorded similar seasonal reproduction in another species of decapod crustacean, Isocheles sawayai Forest and de Saint Laurent 1968, in the north littoral region of Santa Catarina $\left(26^{\circ} 06^{\prime} \mathrm{S}, 48^{\circ} 34^{\prime} \mathrm{W}\right)$ during months of higher temperatures (late spring and summer). The larger body size $(\mathrm{CL})$ of the female E. oplophoroides population in Cananéia is also in accordance with Bauer (1992), who proposed that longevity with growth to larger size tend to increase at higher latitudes.

In the present study, a latitudinal effect can be seen in the respective reproduction of the $E$. oplophoroides populations of Cananéia and Ubatuba to the north. We propose that the lower reproductive output and consequently lower fecundity of the Ubatuba females reflects the fact that females with embryos in their pleopods are found during all months of the year, a pattern characteristic of continuous reproduction (Fransozo et al. 2005). Indeed, the availability of phytoplankton for larval development remains generally low but continuous throughout the year in Ubatuba (Pires-Vanin and Matsuura 1993). In contrast, 
Cananéia females dedicate much of their energy to a unique reproductive period during which they produce a large number of embryos to achieve greater reproductive success, likely due to the seasonality and short duration of suitable periods for reproduction (Morgan 2001).

On the other hand, Ubatuba and Macaé are latitudinally nearby regions, and so, the female E. oplophoroides population should be equals in size, reproductive output and average number of embryos (Bauer 1992). However, the reproductive output and average number of embryos were different between regions with higher values in Macaé. Macaé is located in an area subject to the upwelling phenomenon of Cabo Frio (RJ), which is characterized by ascending deeper cold waters (below $20^{\circ} \mathrm{C}$ ) to the surface of the ocean (Da Silva et al. 2006). Conditioned by physical effects such as the break of the continental shelf, as well as winds associated with the action of oceanic currents and water masses (Cerda and Castro 2014).

The Macaé region is exposed to this upwelling during a good part of the year, affecting all biota distributed to a depth of approximately 10-15 m (Lana et al. 1996; Cerda and Castro 2014; Andrade et al. 2015). Upwelling zones promote the transport of nutrients such as nitrogen and phosphorus to the surface, which become trapped in lower layers of the euphotic zone and have a seasonal influence on primary productivity (Odebrecht and Castello 2001; Gaeta and Brandini 2006).

Thus, we propose that due to the pronounced intra-annual variation in environmental conditions recorded in Macaé that is associated with months of increased food supply, E. oplophoroides females in this region allocate more energy for reproduction during seasons of higher productivity, that is, when feeding conditions for larval development are very favorable. This hypothesis would explain the difference in the number of embryos and reproductive output observed in this region in relation to Ubatuba.

However, not all the characteristics of a species are influenced by environmental conditions; for example, no difference in the volume of embryos was recorded here between the studied populations. In this case, the similarity of the observed values is likely due to the use of the same single species (E. oplophoroides) throughout all regions, since egg size (volume) is exclusively controlled by genotypic factors and rarely by phenotypic factors (Sastry 1983). This in turn plays an important role in defining embryonic development, in terms of both the number of stages and the time required to complete metamorphosis (Chacur and Negreiros-Fransozo 1999).

Egg number and weight exhibited a positive correlation with female size and weight, respectively. This is because the relative number of embryos produced in a single spawn, i.e. individual fecundity, has a linear relationship with the size of the female, with the absolute number of embryos loaded during female spawning determined by both genetic and environmental factors (Valenti et al. 1989). Moreover, the positive relationship between the number of embryos fertilized and the size (CC) of females indicates that fertility increases with an increase in length. Smaller females tend to produce a smaller number of embryos because they possess a smaller ovary and reduced space in the abdomen for incubation (Clarke 1993).

In summary, the distinct reproductive patterns observed in the studied E. oplophoroides populations are directly related to the environmental features of each region, more specifically to seasonal variation in food supply for larval development. Thus, the three populations adjust their reproduction to periods during which environmental conditions are more favorable for the success of their offspring.

\section{Acknowledgments}

We thank many colleagues from the NEBECC group who helped with sampling and laboratory analyses; and the 'Instituto Brasileiro do Meio Ambiente e dos Recursos Naturais Renováveis' (IBAMA) for granting permission to collect the animals.

\section{Disclosure statement}

No potential conflict of interest was reported by the authors.

\section{Funding}

This work was supported by Fundação de Amparo à Pesquisa do Estado de São Paulo - FAPESP [grant number Temático Biota 2010/50188-8]; Coordenação de Aperfeiçoamento de Nível Superior - CAPES - Ciências do Mar II [grant number 23038.004310/2014-85], [grant number 2005/2014 23038.004308/2014-14], Conselho Nacional de Desenvolvimento Científico e Tecnológico - CNPq (Research Scholarships) [grant number PQ 304968/2014-5], [grant number PQ 308653/20149], Fundação para o Desenvolvimento da Unesp - FUNDUNESP [grant number 1214/2010 - DFP]; Pró Reitoria de Pesquisa da Unesp (PROPE).

\section{ORCID}

Gilson Stanski (iD http://orcid.org/0000-0002-4778-7336

Mariana M. Carvalho (iD http://orcid.org/0000-0003-1039-320X

Geslaine R. L. Goncalves (D) http://orcid.org/0000-0001-74436913

Rogério C. Costa (D) http://orcid.org/0000-0002-1342-7340

\section{References}

Andrade LS, Frameschi IF, Costa RC, Castilho AL, Fransozo A. 2015. The assemblage composition and structure of swimming crabs (Portunoidea) in continental shelf waters of southeastern Brazil. Cont Shelf Res. 94:8-16. 
Batoy CB, Camargo JF, Pilapil BC. 1987. Breeding season, sexual maturity and fecundity of the blue crab, Portunus pelagicus (L.) in selected coastal waters in Leyte and vicinity, Philippines. Annu Trop Res. 9:157-177.

Bauer RT. 1992. Testing generalizations about latitudinal variation in reproduction and recruitment patterns with sicyoniid and caridean shrimp species. Invertebr Repr Dev. 22(1-3):193-202.

Castilho AL, Gavio MA, Costa RC, Boschi EE, Bauer RT, Fransozo A. 2007. Latitudinal variation in population structure and reproduction pattern of the endemic South American shrimp Artemesia longinaris (Decapoda: Penaeoidea). J Crustac Biol. 27(4):548-552.

Cerda C, Castro BM. 2014. Hydrographic climatology of South Brazil Bight shelf waters between Sao Sebastiao (24ㅇ) and Cabo Sao Tome (22S). Cont Shelf Res. 89:5-14.

Chacur MM, Negreiros-Fransozo ML. 1999. Biological aspects of the spine-shrimp Exhippolysmata oplophoroides (Holthuis, 1948) (Crustacea, Caridea, Hippolytidae). Rev Bras Biol. 59(1):173-181.

Clarke A. 1987. Temperature, latitude and reproductive effort. Mar Ecol Prog Ser. 38:89-99.

Clarke A. 1993. Reproductive trade-offs in caridean shrimps. Funct Ecol. 7:411-419.

Costa RC, Fransozo A, Mantelatto FL, Castro RH. 2000. Occurrence of shrimp species (Crustacea: Decapoda: Natantia: Penaeidea and Caridea), in Ubatuba Bay, Ubatuba, SP, Brazil. Proceeding of the Biological Society of Washington. 113(3):776-781.

Dall W, Hill BJ, Rothlisberg PC, Sharples DJ. 1990. The biology of the Penaeidae. In: JHS. Blaxter, AJ. Southward, editors. Adv Mar Biol. San Diego (CA): Academic Press; p. 1-489.

Da Silva GL, Dourado MS, Candella RN, Sharples DJ. 2006. Estudo preliminar da climatologia da ressurgência na região de Arraial do Cabo, RJ.

Fingerman M. 1995. Endocrine mechanisms in crayfish, with emphasis on reproduction and neurotransmitter regulation of hormone release. Amer Zool. 35:68-78.

Fransozo V, Costa RC, Bertini G, Cobo VJ. 2005. Population biology of spine shrimp Exhippolysmata oplophoroides (Holthuis)(Caridea, Hippolytidae) in a subtropical region, São Paulo, Brazil. Revista Brasileira de Zoologia. 22(4):1078-1084.

Gaeta AS, Brandini FP, . 2006. Produção primária do fitoplâncton na região entre o Cabo de São Tomé (RJ) e o Chuí (RS). In: CL. Rossi-Wongtschowski, MSP. Madureira, editors. O Ambiente Oceanográfico da Plataforma Continental e do Talude na Região Sudeste-Sul do Brasil. São Paulo: EDUSP; p. 219-264.

Garcia JR, Wolf MR, Costa RC, Castilho AC. 2016. Growth and reproduction of the shrimp Rimapenaeus constrictus (Decapoda: Penaeidae) from the southeastern coast of Brazil. Regional Studies in Marine Science. 6:1-9.

Goodbody H. 1965. Continuos breeding in populations of two tropical crustaceans, Mysidium columbiae (Zimmer) and Emerita portoricensis Schmidt. Ecology. 46:195-197.

Kutner MB. 1972. Variação estacional e distribuição do fitoplâncton na região de Cananéia. Tese para obtenção do título de 'Doutor em Ciências'. Instituto Oceanográfico da USP.

Lana PC, Camargo MG, Brogim RA, Isaac VJ. 1996. O Bentos da Costa Brasileira: Avaliação Crítica e Levantamento Bibliográfico. Rio de Janeiro: FEMAR.
Lancaster I. 1990. Reproduction and life history strategy of the hermit crab Pagurus bernhardus. J Marine Biol Assesment UK. 70:129-142.

Laufer H, Landau M. 1991. Endocrine control of reproduction in shrimp and other Crustacea. In: PF. Loach, WJ. Dougherty, MA. Davidson, editors. Developments in aquaculture and fisheries science: frontiers of shrimp research. Amsterdam: Elsevier; p. VII+294p, 22.

Little G. 1968. Induced Winter breeding and larval development in the shrimp, Palaemonetes pugio Holthuis (Caridea, Palaemonidae). Crustaceana. 2:19-26.

Morgan SG. 2001. The larval ecology of marine communities. In: Bertness MD, Gaines SD, Hay ME, editors. Marine community ecology. Sunderland (MA): Sinauer Associates; p. 159-181.

Odebrecht C, Castello JP. 2001. The convergency ecosystem in the southwest Atlantic. In: U. Seeliger, B. Kjerfve, editors. Ecological studies costal marine ecosystem of Latin America. Berlin: Springer - Verlag; p. 360, 22.

Pezzuto PR, Benincà EM. 2015. Challenges in licensing the industrial double-rig trawl fisheries in Brazil. Latin Am J Aquat Res. 43(3):495-513.

Pires-Vanin AMS, Matsuura Y. 1993. Estrutura e função do ecossistema de plataforma continental da região de Ubatuba, estado de São Paulo: uma introdução. Publicação especial do Instituto Oceanográfico. 10:1-8.

Quackenbush LS. 1994. Lobster reproduction: a review. Crustaceana. 67(1):82-94.

Sastry AN. 1983. Ecological aspects of reproduction. In: FJ. Vernberg, WB. Vernberg, editors. The biology of crustacea. Vol. 8. Amsterdam: Environmental Adaptations; pp. 179-270.

Stanski G, Castilho AL. 2016. Reproductive biology of the South American endemic hermit crab (Crustacea, Anomura) from the Southern coast of Brazil. Invertebrate Reproduction \& Development. 60 (2): 103-111.

Terossi M, Wehrtmann I, Mantelatto FL. 2010. Interpopulation comparison of reproduction of the Atlantic Shrimp Hippolyte obliquimanus (Caridea: Hippolytidae). J Crustac Biol. 30(4):571-579.

Thorson G. 1950. Reproductive and larval ecology of marine bottom invertebrates. Biol Rev. 25:1-45.

Turner RL, Lawrence JM. 1979. Volume and composition of echinoderm embryos: implications for use of embryos size in life-history models. In: Stancky SE, editor. Reprod Ecol Mar Invertebrates. Belle W. Baruch Institute; p. 25-40.

Valentini H, D'Incao F Roodriguez LF, Rebelo Neto JE, Domit LG. 1991. Análise da pesca do camarão-sete-barbas (Xiphopenaeus kroyeri) nas regiões Sudeste e Sul doBrasil. Atlântica, Rio Grande. 13:171-177.

Valenti WC, Mello JTC, Lobão VL. 1989. Fecundidade em Macrobrachium acanthurus (Wiegmann, 1836) do Rio Ribeira de Iguape (Crustacea, Decapoda, Palaemonidae). Revista Brasileira de Zoologia. 6(1):9-15.

Warner GF. 1977. The biology of crabs. London: Elekscience; $p$. 202p.

Williams AB. 1984. Shrimps, lobsters and crabs of the Atlantic coast of the eastern United States, Maine to Florida. Washington: Smithsonian Institution press; p. 550.

Zar JH. 1999. Biostatistical analysis. 4th ed. Prentice Hall. p. 663. 